\title{
Circulating Tumor DNA in Biliary Tract Cancer: Current Evidence and Future Perspectives
}

\author{
ALESSANDRO RIZZO*, ANGELA DALIA RICCI*, SIMONA TAVOLARI and GIOVANNI BRANDI \\ Department of Experimental, Diagnostic and Specialty Medicine, \\ S. Orsola-Malpighi University Hospital, Bologna, Italy
}

\begin{abstract}
Peripheral blood of cancer patients "physiologically" presents cells and cellular components deriving from primary or metastatic sites, including circulating tumor cells (CTCS), circulating free DNA (cfDNA) and exosomes containing proteins, lipids and nucleic acids. The term circulating tumor DNA (ctDNA) indicates the part of $C$ DNA which derives from primary tumors and/or metastatic sites, carrying tumor-specific genetic or epigenetic alterations. Analysis of ctDNA has enormous potential applications in all stages of cancer management, including earlier diagnosis of cancer, identification of driver alterations, monitoring of treatment response and detection of resistance mechanisms. Thus, ctDNA has the potential to profoundly change current clinical practice, by moving from tissue to peripheral blood as a source of information. Herein, we review current literature regarding the potential role for ctDNA in biliary tract cancer (BTC) patients, with a particular focus on stateof-the-art techniques and future perspectives of this highly aggressive disease.
\end{abstract}

Biliary tract cancers (BTCs) include a heterogeneous group of malignancies usually classified in the following subgroups, according to anatomical location: intrahepatic cholangiocarcinoma (iCCA), extrahepatic cholangiocarcinoma (eCCA),

This article is freely accessible online.

*These Authors contributed equally to this study.

Correspondence to: Alessandro Rizzo, Medical Doctor, Division of Medical Oncology, S.Orsola-Malpighi Hospital, University of Bologna, Bologna, Italy. Tel: +39 0512144078, Fax: +39 0516364037, e-mail: rizzo.alessandro179@gmail.com

Key Words: Liquid biopsy, biliary tract cancer, cholangiocarcinoma, ctDNA, cfDNA, review. gallbladder cancer (GBC) and ampulla of Vater cancer (AVC) (1-3). The term cholangiocarcinoma includes iCCA and eCCA, which in turn comprises perihilar cholangiocarcinoma (pCCA) and distal cholangiocarcinoma (dCCA) $(4,5)$. Although the anatomical classification of BTC may be considered simplistic, it faithfully reflects the differentiation of BTC subgroups in terms of epidemiology, etiology, clinical presentation, molecular features and therapeutic approaches $(6,7)$. BTC currently represents about $3 \%$ of all gastrointestinal malignancies and the second most common primary liver cancer (PLC), following hepatocellular carcinoma (HCC) (8, 9). Even though BTC is considered an uncommon cancer in Western countries, its incidence is increasing, and perhaps is associated with the increasing incidence of iCCA and partly as a result of better disease recognition (10-12). An important geographical variation in BTC epidemiology has been historically observed, with higher incidence rates in geographical areas where liver fluke infestation (Opistorchis viverrini and Clonorchis sinensis) is more common such as Korea, Japan, China and Thailand $(13,14)$. More specifically, Northeast Thailand presents the highest BTC rate worldwide, with an annual incidence of 95/100,000 inhabitants and representing more than $80 \%$ of all PLCs in this region $(15,16)$. Other countries such as India and Chile depict high incidence of $\mathrm{GBC}$, given the high prevalence of chronic hepatolithiasis $(17,18)$. Apart from these risk factors, primary sclerosing cholangitis (PSC), cirrhosis, chronic hepatitis C and B infection, fatty liver disease and asbestos exposure have been associated with an increased risk of developing BTC (19-22).

Although surgery remains the mainstay of cure in early stages, the majority of BTC patients are diagnosed with advanced-stage disease, therefore precluding any surgical management $(23,24)$. Cisplatin plus gemcitabine combination chemotherapy is considered the standard firstline treatment in advanced, unresectable BTC, following the results of the ABC-02 landmark trial (25). Despite ABC-02 trial representing a historical step forward in medical 
treatment for advanced BTC, the survival gain provided by first-line chemotherapy is modest since nearly all patients develop progressive disease following front-line treatment, with a median overall survival (OS) of less than a year (26). More recently, although outstanding advances in genomic sequencing have given hope to new treatment strategies, BTC patients still have a poor prognosis with short life expectancy (27-29).

In the last decade, liquid biopsy has received growing attention because of its promising applications in patients with cancer $(30,31)$. In fact, liquid biopsy, based on circulating free DNA (cfDNA), circulating tumor cells (CTCs), circulating cell-free RNA (ccfRNA) and circulating tumor DNA (ctDNA), represents a potential tool which could bring a new insight into cancer diagnosis and management (Figure 1) $(32,33)$. More specifically, this new technology has the potential to reveal cancer-specific genetic and epigenetic features directly in the bloodstream $(34,35)$; if the term cfDNA indicates DNA which is freely circulating but not necessarily of tumor origin, ctDNA represents a tumor-derived fragmented DNA which is released into the bloodstream $(36,37)$. More specifically, the majority of cfDNA comes from normal cells; conversely, a small part of cfDNA directly comes from primary tumors, metastatic sites or CTCs, and it is called ctDNA (38-40). The possibility to detect biological, tumor-derived material circulating in body fluids may have remarkable applications in any phase of cancer management in terms of earlier diagnosis, detection of relapse, identification of therapeutic targets, monitoring of treatment response and tracking emergence of resistance (41-44).

Herein, we review current literature regarding the potential clinical role of ctDNA in BTC management, with a particular focus on current state of art and possible future directions.

\section{Current Limits in Diagnosis of BTC: Blood-based Markers, Imaging and Histology}

Although multiple diagnostic methods are currently available, the diagnosis of BTC remains challenging $(45,46)$. In clinical practice, CA19-9 and carcinoembryonic antigen (CEA) are the most frequently used blood-based tumor markers $(47,48)$. However, CA 19-9 (with a cut-off $>129 \mathrm{U} / \mathrm{ml}$ ) represents the only recommended biomarker for clinical use, according to the ESMO guidelines for BTC (49); besides, overall sensitivity of CA19-9 remains controversial since high levels of CA19-9 may be encountered in several other malignancies, in benign cholestasis and after hepatic injuries (50). Lastly, various cut-off values have been proposed, usually between $100 \mathrm{U} / \mathrm{ml}$ and $200 \mathrm{U} / \mathrm{ml}$ (51).

Ultrasonography, computed tomography (CT) and magnetic resonance imaging (MRI) are important techniques for diagnosis and staging (52). At ultrasonography, iCCA appear as solid mass lesions while pCCA and dCCA are more difficult to identify using ultrasound (53); conversely, MRI is considered the modality of choice in BTC diagnosis, given the high contrast resolution and the ability to determine the vascular, biliary and parenchymal extension of the neoplasm (54).

Pathological confirmation of diagnosis is necessary before any non-surgical treatment and can be challenging in BTC, particularly in patients affected by PSC and biliary strictures (55). Decisions to undertake biopsies should follow a multidisciplinary discussion, especially in potentially resectable tumors (56). Endoscopic imaging and tissue sampling are useful but, unfortunately, biopsy samples are often inadequate for molecular profiling (57), and in addition, tissue sampling has reported high specificity but low sensitivity in diagnosis of malignant biliary strictures (58). Lastly, the highly desmoplastic nature of BTC limits the accuracy of cytological and pathological approaches (59). In this scenario, it is urgent to develop new strategies in order to anticipate the diagnosis identifying BTC at an early, resectable stage, and obtain sufficient material with which to perform genomic analysis.

\section{Genomic Profiling of BTC}

Recent efforts in genomic sequencing and molecular subtyping have paved the way towards a new era in BTC management (60). In fact, the advances in the comprehension of BTC molecular landscape have recently provided new keys to identify prognostic and predictive biomarkers as well as mechanisms of resistance and pathogenesis (61). More specifically, almost $50 \%$ of BTCs are supposed to harbor at least one driver mutation, and to date, several targeted agents have shown promising results in recent clinical trials $(62,63)$.

Firstly, Javle et al. suggested a correlation between genomic features and clinical outcomes, on the basis of data extracted from the FoundationOne platform (64). According to that study, KRAS was the most common aberration in eCCA (42\% of cases), ERBB2 in GBC (16\%) and IDH1 and FGFR in iCCA; moreover, FGFR mutations seemed to be associated with a good prognosis, according to the study. More recently, a multicenter study on 489 BTCs from 10 countries suggested the presence of 4 molecular clusters of BTC, on the basis of integrative clustering analysis of mutations, combined whole-genome, copy-number, gene expression and DNA methylation data (65). In this study, Cluster 1 mainly included fluke-positive malignancies with ERBB2 amplification, TP53 and ARID1A alterations; conversely, Cluster 4 identified fluke-negative iCCA with FGFR aberrations and $\mathrm{CpG}$ shore hypermethylation. Moreover, better OS was observed in Cluster 4, thus supporting previous findings from Javle et al. regarding the role of FGFR aberrations. 


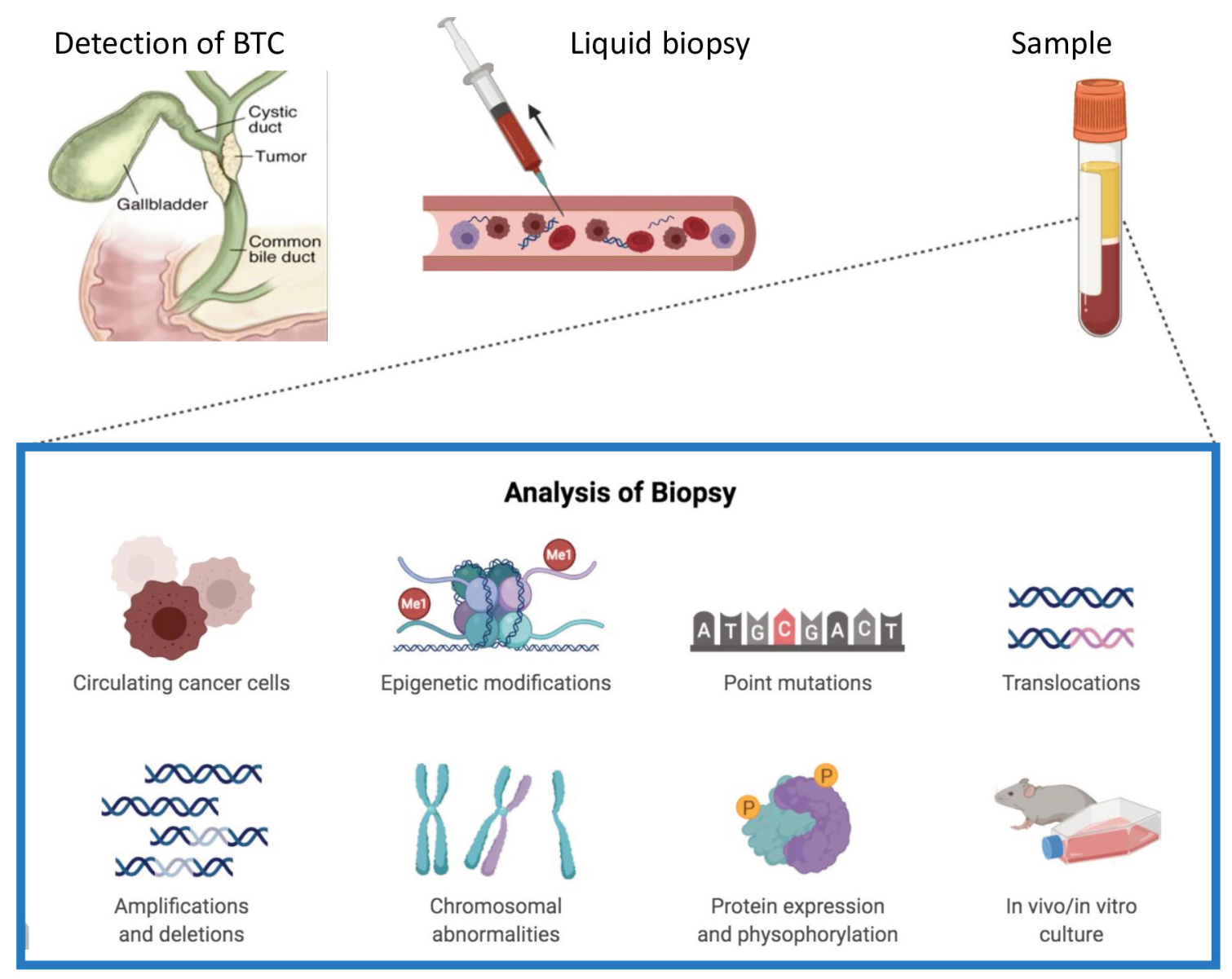

Figure 1. Schematic figure of liquid biopsy as a source of information.

As stated above, these aberrations and molecular features represent potential therapeutic targets in specific anatomic subtypes. The recent prospective MOSCATO-1 trial analyzed 1,035 tumor samples and matched, on the basis of genetic aberrations, 199 patients to specific targeted therapies (66). Among them, 18 patients were affected by previously treated, advanced BTC; interestingly, in BTC patients receiving targeted therapies ORR was $33 \%$ and PFS and OS were 5.2 months and 17 months, respectively.

A plethora of previous studies on BTC have grouped together patients with different anatomical and molecular subtypes, something which represents the "original sin" of several clinical trials which do not do justice to the marked inter- and intra-tumoral heterogeneity of BTC (67-69). The modest survival benefit observed with current treatment options emphasizes the need for new affective agents and tailor-made trials based on genetic profile and histological features characterizing BTC (70). The emergence of targeted treatments in BTC is challenging previous treatment paradigms, especially for iCCA for whom targeting FGFR fusions and IDH1/IDH2 mutations is becoming part of current clinical practice (71-73).

\section{Between Two Worlds: ctDNA Assay and Tissue-based Assay}

Tumor biopsies are the gold standard for cancer diagnosis and the primary tool for molecular testing, guiding treatment selection (74). Nevertheless, sampling tissue is an invasive and often anatomically difficult method; moreover, conventional tissue biopsies are not always feasible, they frequently need to be repeated and it is not easy to obtain sufficient material of proper quality for cancer genome profiling (75).

Conversely, the analysis of ctDNA has the potential to overcome the abovementioned limitations, by capturing the outstanding spatial and temporal tumor heterogeneity and expanding the opportunity for real-time monitoring (76). 
Table I. Tissue-based assay vs. ctDNA assay.

\begin{tabular}{|c|c|}
\hline Tissue-based assay & ctDNA assay \\
\hline \multicolumn{2}{|l|}{ Disadvantages } \\
\hline $\begin{array}{l}\text { Time-intensive procedure } \\
\text { Localized sampling of tissue } \\
\text { Sampling is not easily carried out (tumor tissue ins } \\
\text { Invasive procedure }\end{array}$ & $\begin{array}{l}\text { Limited evidence for treatment selection } \\
\text { Low correlation with histology/cellular phenotype }\end{array}$ \\
\hline \multicolumn{2}{|l|}{ Advantages } \\
\hline $\begin{array}{l}\text { Substantial evidence for treatment selection } \\
\text { High correlation with histology/cellular phenotype }\end{array}$ & $\begin{array}{l}\text { Fast } \\
\text { Comprehensive tissue profile } \\
\text { Easy sampling } \\
\text { Minimally invasive testing } \\
\text { Easily repeatable technique }\end{array}$ \\
\hline
\end{tabular}

Thus, liquid biopsy is emerging as a promising, attractive molecular diagnostic tool with minimal invasiveness (77). Compared to classic tissue biopsies, the analysis of ctDNA is quick, simple and presents minimal procedural risk (Table I), considering that blood, saliva or urine are easier to access than tissue biopsy (78). In fact, although liquid biopsy is commonly referred to peripheral blood analysis, this term includes the collection and analysis of cancer-derived material from other bodily fluids such as saliva, bile, urine, stool, cerebrospinal fluid, ascites and pleural fluid (79). Overall, liquid biopsy is the natural "partner" of tailor-made, personalized oncology approach, having the potential to capture tumor spatio-temporal heterogeneity and providing a more "holistic" view of tumor (80-82).

Limitations of cfDNA/ctDNA analysis include lack of spatial specificity for anatomically critical and clinically relevant lesions, low shedding of ctDNA by certain malignancies and the lack of prospective validation for clinical practice for a majority of cancers $(83,84)$. Moreover, currently available ctDNA assays are not able to detect a number of genes compared to tissue-based panels, a critical issue which modern technologies are trying to face (85-87).

\section{Clinical Applications of ctDNA/cfDNA Analysis}

In 1948, Mandel and Métais were the first to identify fragmented DNA in the non-cellular component of the blood, which was called cfDNA (88). Twenty-nine years after the first identification of cfDNA, Leon et al. observed increased levels of cfDNA in cancer patients compared to healthy controls (89). Since then, an accumulating body of literature has investigated CTCs, ctDNA and cfDNA as novel biomarkers, with the aim to facilitate early detection of malignancies and improve the prognosis of cancer patients
(90-92). On the basis of current knowledge, the mechanisms of apoptosis and necrosis have been identified as important contributors to cfDNA release into the bloodstream (93). In physiological conditions, cfDNA derived from cells is found in plasma at low concentrations which may be influenced by several stressing situations (e.g. physical exercise, surgery, inflammation, etc.) (94). As previously stated, the proportion of cfDNA which is specifically released from tumor cells is currently called ctDNA, who in turn may represent from $0.1 \%$ to $90 \%$ of overall cfDNA (95). The applications of cfDNA/ctDNA can be schematically summarized by five categories (Table II): diagnosis, detection of tumor burden, prognosis, selection of treatment and monitoring for relapse/treatment efficacy.

With regard to diagnosis, early detection methods are under active investigation (96). In particular, the diagnosis of cancer at an early stage remains a challenge in several malignancies, given the frequent "silent" clinical character of early-stage disease and, in many cases, even of advanced cancer (97). Therefore, identifying early-stage malignancies would mean better chance of cure making cfDNA analysis an extremely attractive tool (98). Unfortunately, this approach would need an extremely sensitive method in order to detect minimal amounts of cfDNA released into the bloodstream and to date, no technology currently exists to reach this goal (99).

In the current era of precision cancer therapies, the choice of treatment is often based on tumor molecular profile and the clinical benefit of tailor-made agents is limited by the emergence of acquired resistance (100). In this landscape, ctDNA has the potential to assess molecular profile with a quick and minimally invasive procedure such as a simple blood draw (101). Despite early studies detected low concordance between tumor and plasma samples, recent and 
Table II. Highlights of current and future applications of ctDNA in cancer management.

\begin{tabular}{|c|c|}
\hline Diagnosis & $\begin{array}{l}\text { The majority of studies have shown poor sensitivity, especially for early stage disease } \\
\text { For small tumors, not enough ctDNA to provide an accurate test result } \\
\text { Need for further validation, in order to allow early intervention and curative surgery }\end{array}$ \\
\hline Tumor burden & $\begin{array}{l}\text { Larger amount of ctDNA=advanced tumor stage/greater metastatic burden } \\
\text { ctDNA has the potential to "capture" tumor burden in different moments of the disease, } \\
\text { given the possibility to repeat blood testing more often than imaging/traditional biopsies }\end{array}$ \\
\hline Prognosis & $\begin{array}{l}\text { Absence of ctDNA after radical surgery has been associated with better } \\
\text { prognosis and smaller risk of relapse in several malignancies } \\
\text { Future perspectives: the possibility to determine the necessity of adjuvant therapy } \\
\text { and the true risk of relapse }\end{array}$ \\
\hline Treatment & $\begin{array}{l}\text { Sequencing the ctDNA may guide choice of therapy, targeting specific mutations } \\
\text { ctDNA analysis captures tumor heterogeneity, a key element towards more targeted treatment }\end{array}$ \\
\hline Monitoring for relapse/treatment efficacy & $\begin{array}{l}\text { ctDNA concentrations follow the evolution of the disease, indicating relapse/treatment } \\
\text { failure before clinical practice/imaging } \\
\text { ctDNA has the potential to monitor response to treatment and the onset of new mutations }\end{array}$ \\
\hline
\end{tabular}

larger studies have suggested concordance rates from $80 \%$ to $90 \%$ between the two samples, particularly in key driver genes $(102,103)$. Nevertheless, a proportion of patients affected by metastatic disease (estimated at about 10-15\%) may not present sufficient cfDNA/ctDNA levels to permit mutational profiling from plasma, a key element to consider when interpreting the results of cfDNA/ctDNA analysis (104).

During medical treatment, liquid biopsy may detect emergent genetic alterations driving acquired therapeutic resistance (105); thus, serial liquid biopsies may be useful tools to identify resistant mutations and to change treatment in real time, avoiding invasive tumor biopsies (106). Therefore, liquid biopsy has rapidly emerged as an extremely promising technology, due to the ability to capture tumor molecular heterogeneity and the clonal outgrowth of resistant subclones (107). Interestingly, the main and earliest example of the application of cfDNA/ctDNA testing for the management of therapeutic resistance is epidermal growth factor receptor (EGFR)-mutated non-small cell lung cancer (NSCLC) $(108,109)$. In this setting, cfDNA analysis may detect the emergence of EGFR T790M mutation during EGFR inhibitor therapy - with a high level of concordance observed between the results of tissue testing and liquid biopsy - and also the coexistence of other resistance mechanisms, such as MET amplification (110). Other possible applications of cfDNA/ctDNA include the identification of prognostic and predictive biomarkers, detection of postsurgical residual disease, tracking of therapeutic response and the detection of recurrence (111, 112). Despite the fact that liquid biopsy may pave the way for a revolution in medical oncology, a careful understanding of limitations and advantages of this approach is mandatory to properly interpret the analysis and to correctly guide clinical decision making.

\section{The Use of ctDNA in BTC}

Although liquid biopsy may present an attractive diagnostic tool in early-stage BTC, very few data are currently available and the advances in the field have been hampered by technical challenges primarily due to the frequently low levels of ctDNA in patients with localized disease (113). As stated above, the difficulty in obtaining sufficient cytologic material to confirm the diagnosis and to perform genomic analysis is particularly challenging in BTC, whose poor prognosis is in part due to late diagnosis (114). Thus, ctDNA could play a particularly important role in BTC patients, since biopsy samples are often inadequate for molecular profiling, especially in eCCA and GBC (115).

In a prospective analysis of 26 pancreatobiliary malignancies, Zill et al. reported high concordance between mutations detected in tumor biopsies and cfDNA (116). This study included 8 patients with BTC and 18 with pancreatic cancer; cfDNA identified the $90.3 \%$ of mutations detected in tissue biopsies.

A study by Kumari et al. recently assessed the role of cfDNA in the diagnosis of GBC (117). Serum was collected from 34 GBC patients and 39 sex- and age-matched controls, 22 of which with cholecystitis and 17 patients without comorbidities. In this study, which represented the first to evaluate serum cfDNA in GBC, the authors used real-time PCR assay to quantify amount of cfDNA, comparing the three cohorts of patients (117). Interestingly, cfDNA was found to be significantly lower in cholecystitis controls and healthy subjects compared to the GBC group. Moreover, cfDNA was significantly associated with jaundice, metastatic lymph nodes and stage, according to TNM system (117). Thus, cfDNA quantitative analysis could play an important role in distinguishing inflammatory disorders and GBC and may serve as novel, noninvasive marker for GBC diagnosis. 
In another study on 69 cholangiocarcinoma patients (94\% with pCCA) and 95 healthy sex- and age-matched controls, cfDNA analysis identified a panel of four genes (HOXA1, PRKCB, CYP26C1, and PTGDR) which had differentially methylated regions (DMRs) in CCA patients (118). The panel showed a specificity of $93 \%$ and a sensitivity of $83 \%$ in the detection of cholangiocarcinoma; interestingly, the DMR ctDNA panel detected 32 (80\%) of the 40 CCAs which were deemed eligible for surgical resection or transplantation and $15(60 \%)$. Overall, the sensitivity of cfDNA/ctDNA mutations for early stage BTC is currently unknown.

As previously stated, sequencing of tissue samples may be limited by low tumoral content, thus liquid biopsy is being harnessed for genomic profiling of BTC (119). In a study by Andersen and Jakobsen, the authors proposed a multiplex digital PCR method of screening for 31 mutations in KRAS, NRAS, BRAF and PIK3CA genes in patient plasma (120). Interestingly, the assay was firstly confirmed in pooled normal serum and positive controls; therefore, the assay was conducted on serum of six wild-type patients for the assayed mutations and five BTC patients with proven tumor mutations. Mutations found in the tumor were in parallel found in the plasma of all the "mutated" patients and, at the same time, there was a perfect agreement in wild-type status between tumor and plasma (120).

In another study, Mody et al. performed a ctDNA analysis on 138 samples of BTC patients, finding at least one genomic alteration in $89 \%$ of cases (121). Interestingly, the majority of cases included in this study were iCCAs, something which represents the main limitation of this study since iCCAs are the BTC subgroup for which liver biopsies and tissue sampling are easier. Although the most frequently detected alterations were TP53, KRAS and FGFR2, the proper and parallel concordance between ctDNA and tissuebased alterations has yet to be assessed in larger cohorts of patients (121).

Another role for ctDNA/cfDNA is represented by monitoring response to chemotherapy and targeted therapy, thus tracking emergence of resistance $(122,123)$. In a German study, ctDNA and tumor tissue samples were collected from 24 BTC patients before and during chemotherapy; the two samples were subjected to deep sequencing of 15 frequently mutated genes in BTC, including TP53, ARID1A, KRAS, IDH1, BAP1, PBRM1, SMAD4, PIK3CA, FBXW7, CDKN2A, ERBB2, NRAS, IDH2, BRAF and BLC2 (124). Interestingly, ctDNA in blood compared to tissue had a concordance of $74 \%$ in all patients and $92 \%$ in the iCCA cohort; moreover, $63 \%$ of chemotherapy-naïve patients had their mutational profile changed during treatment. Lastly, ctDNA variant allele frequency (VAF) showed a strict correlation with progression-free survival (PFS) and tumor load.
As previously stated, FGFR2 genomic alterations are the most frequently observed aberrations in iCCA, with a prevalence ranging from $13-45 \%$ and a mutual exclusivity with KRAS/BRAF mutation $(125,126)$. In recent years, the role of FGFR-targeted therapies has been tested in a number of clinical trials and various agents have been evaluated or are currently under investigation including multitarget tyrosine kinase inhibitors as well as specific anti-FGFR2 antibodies including BGJ39 (127). Goyal et al. recently analyzed cfDNA collected by serial sampling in 4 patients enrolled in a Phase II trial assessing the role of BGJ39 (128). Among the 4 patients, 3 experienced significant tumor regression followed by short interval disease progression. Serial analysis of cfDNA at enrollment and after progression showed the presence of the V564F acquired mutation at the time of progression and, in 2 patients, multiple point mutations in the FGFR portion of the fusion genes (128). Moreover, a high concordance was observed between tissue and plasma measurements, since tumor biopsy of the postprogression lesions and postmortem analysis agreed with cfDNA analysis, identifying marked intratumor heterogeneity and de novo point mutations conferring resistance to the FGFR inhibitor (128). Although based on a small subgroup of patients, the study highlighted the potential advantages of cfDNA in BTC targeted therapy, where real-time detection of resistance mutations and monitoring of clonal evolution may provide extremely useful information to guide the selection of treatment.

Lastly, the option to use the bile as source for DNA sequencing in BTC has been recently investigated and deserves to be mentioned, since bile is another component of liquid biopsy. A recent study by Shen et al. from 10 BTC patients (including 4 cases of GBC) suggested that bile cfDNA could consist of long fragments, with a high correspondence between molecular features detected in bile and tissue sampling (129). Studies on larger cohorts of patients are needed to confirm the above results and to further assess the role of bile as source of cfDNA.

\section{Conclusion}

The applications of ctDNA/cfDNA on tumor detection, characterization and genetic assessment have the potential to pave the way towards a new era in cancer management. Although few data are currently available regarding ctDNA analysis in BTC, this cost-effective, fast and non-invasive test may contribute to the implementation of precision medicine and improve clinical outcomes in a highly aggressive and increasingly frequent disease.

\section{Conflicts of Interest}

No potential conflict of interest was reported by the Authors. 


\section{Authors' Contributions}

AR, ADR: Made substantial contributions to the conception of the study and drafted the article; ST, GB: critically revised the article and gave final approval of the version to be published. All Authors critically revised the article, approved the final version to be published, and agree to be accountable for all aspects of the work.

\section{References}

1 Khan SA, Tavolari S and Brandi G: Cholangiocarcinoma: Epidemiology and risk factors. Liver Int 39(Suppl 1): 19-31, 2019. PMID: 30851228. DOI: 10.1111/liv.14095

2 Adeva J, Sangro B, Salati M, Edeline J, La Casta A, Bittoni A, Berardi R, Bruix $\mathrm{J}$ and Valle JW: Medical treatment for cholangiocarcinoma. Liver Int 39(Suppl 1): 123-142, 2019. PMID: 30892822. DOI: 10.1111/liv.14100

3 Rizzo A, Frega G, Ricci AD, Palloni A, Abbati F, DE Lorenzo S, Deserti M, Tavolari S and Brandi G: Anti-EGFR monoclonal antibodies in advanced biliary tract cancer: A systematic review and meta-analysis. In Vivo 34(2): 479-488, 2020. PMID: 32111744. DOI: 10.21873 /invivo.11798

4 Rizvi S and Gores GJ: Pathogenesis, diagnosis, and management of cholangiocarcinoma. Gastroenterology 145(6): 1215-1229, 2013. PMID: 24140396. DOI: 10.1053/j.gastro.2013.10.013

5 Razumilava N and Gores GJ: Cholangiocarcinoma. Lancet 383(9935): 2168-2179, 2014. PMID: 24581682. DOI: 10.1016/S0140-6736(13)61903-0

6 Rizvi S, Khan SA, Hallemeier CL, Kelley RK and Gores GJ: Cholangiocarcinoma - evolving concepts and therapeutic strategies. Nat Rev Clin Oncol 15(2): 95-111, 2018. PMID: 28994423. DOI: 10.1038/nrclinonc.2017.157

7 Patel T: Worldwide trends in mortality from biliary tract malignancies. BMC Cancer 2: 10, 2002. PMID: 11991810. DOI: $10.1186 / 1471-2407-2-10$

8 Fornaro L, Cereda S, Aprile G, Di Girolamo S, Santini D, Silvestris N, Lonardi S, Leone F, Milella M, Vivaldi C, Belli C, Bergamo F, Lutrino SE, Filippi R, Russano M, Vaccaro V, Brunetti AE, Rotella V, Falcone A, Barbera MA, Corbelli J, Fasola G, Aglietta M, Zagonel V, Reni M, Vasile E and Brandi G: Multivariate prognostic factors analysis for second-line chemotherapy in advanced biliary tract cancer. Br J Cancer 110(9): 2165-2169, 2014. PMID: 24714745. DOI: 10.1038/bjc.2014.190

9 De Lorenzo S, Tovoli F, Barbera MA, Garuti F, Palloni A, Frega G, Garajova I, Rizzo A, Trevisani F and Brandi G: Metronomic capecitabine $v s$. best supportive care in Child-Pugh B hepatocellular carcinoma: a proof of concept. Sci Rep 8: 9997, 2018. PMID: 29968763. DOI: 10.1038/s41598-01828337-6

10 Jepsen P, Vilstrup H, Tarone RE, Friis S and Sorensen HT: Incidence rates of intra- and extrahepatic cholangiocarcinomas in Denmark from 1978 through 2002. J Natl Cancer Inst 99(11): 895-897, 2007. PMID: 17551150. DOI: 10.1093/jnci/djk201

11 Brandi G, Farioli A, Astolfi A, Biasco G and Tavolari S: Genetic heterogeneity in cholangiocarcinoma: a major challenge for targeted therapies. Oncotarget 6(17): 14744-14753, 2015. PMID: 26142706. DOI: 10.18632/oncotarget.4539

12 Shaib YH, Davila JA, McGlynn K and El-Serag HB: Rising incidence of intrahepatic cholangiocarcinoma in the United
States: a true increase? J Hepatol 40(3): 472-477, 2004. PMID: 15123362. DOI: 10.1016/j.jhep.2003.11.030

13 Saha SK, Zhu AX, Fuchs CS and Brooks GA: Forty-year trends in cholangiocarcinoma incidence in the US: intrahepatic disease on the rise. Oncologist 21: 594-599, 2016. PMID: 27000463. DOI: 10.1634/theoncologist.2015-0446

14 Smittenaar CR, Petersen KA, Stewart K and Moitt N: Cancer incidence and mortality projections in the UK until 2035. Br J Cancer 115(9): 1147-1155, 2016. PMID: 27727232. DOI: 10.1038/bjc.2016.304

15 Palmer WC and Patel T: Are common factors involved in the pathogenesis of primary liver cancers? A meta-analysis of risk factors for intrahepatic cholangiocarcinoma. J Hepatol 57(1): 69-76, 2012. PMID: 22420979. DOI: 10.1016/j.jep.2012.02.022

16 Khan SA, Taylor-Robinson SD, Toledano MB, Beck A, Elliott $\mathrm{P}$ and Thomas HC: Changing international trends in mortality rates for liver, biliary and pancreatic tumours. J Hepatol 37: 806-813, 2002. PMID: 12445422. DOI: 10.1016/s01688278(02)00297-0

17 Lin CC, Lin PY and Chen YL: Comparison of concomitant and subsequent cholangiocarcinomas associated with hepatolithiasis: clinical implications. World J Gastroenterol 19(3): 375-380, 2013. PMID: 23372360. DOI: 10.3748/wjg.v19.i3.375

18 Tyson GL and El-Serag HB: Risk factors for cholangiocarcinoma. Hepatology 54(1): 173-184, 2011. PMID: 21488076. DOI: $10.1002 /$ hep.24351

19 Zhang H, Zhu B, Zhang H, Liang J and Zeng W: HBV infection status and the risk of cholangiocarcinoma in Asia: a metaanalysis. Biomed Res Int 2016: 3417976, 2016. PMID: 27999794. DOI: $10.1155 / 2016 / 3417976$

20 Brandi $G$ and Tavolari S: Asbestos and intrahepatic cholangiocarcinoma. Cells 9(2), 2020. PMID: 32059499. DOI: 10.3390/cells9020421

21 Sastry AV, Abbadessa B, Wayne MG, Steele JG and Cooperman AM: What is the incidence of biliary carcinoma in choledochal cysts, when do they develop, and how should it affect management? World J Surg 39(2): 487-492, 2015. PMID: 25322698. DOI: $10.1007 / \mathrm{s} 00268-014-2831-5$

22 Jang MH, Lee YJ and Kim H: Intrahepatic cholangiocarcinoma arising in Caroli's disease. Clin Mol Hepatol 20(4): 402-405, 2014. PMID: 25548748. DOI: $10.3350 / \mathrm{cmh} .2014 .20 .4 .402$

23 Farioli A, Straif K, Brandi G, Curti S, Kjaerheim K, Martinsen JI, Sparen P, Tryggvadottir L, Weiderpass E, Biasco G, Violante FS, Mattioli S and Pukkala E: Occupational exposure to asbestos and risk of cholangiocarcinoma: a population-based case-control study in four Nordic countries. Occup Environ Med 75(3): 191-198, 2018. PMID: 29133597. DOI: 10.1136/oemed-2017-104603

24 Forner A, Vidili G, Rengo M, Bujanda L, Ponz-Sarvisé M and Lamarca A: Clinical presentation, diagnosis and staging of cholangiocarcinoma. Liver Int 39(Suppl 1): 98-107, 2019. PMID: 30831002. DOI: 10.1111/liv.14086

25 Valle J, Wasan H, Palmer DH, Cunningham D, Anthoney A, Maraveyas A, Madhusudan S, Iveson T, Hughes S, Pereira SP, Roughton $\mathrm{M}$ and Bridgewater $\mathrm{J}$; ABC-02 Trial Investigators: Cisplatin plus gemcitabine versus gemcitabine for biliary tract cancer. N Engl J Med 362: 1273-1281, 2010. PMID: 20375404. DOI: $10.1056 /$ NEJMoa0908721

26 Brandi G, Rizzo A, Dall'Olio FG, Felicani C, Ercolani G, Cescon M, Frega G, Tavolari S, Palloni A, De Lorenzo S, Abbati F, 
Mollica V, Ricci AD and Serra C: Percutaneous radiofrequency ablation in intrahepatic cholangiocarcinoma: a retrospective single-center experience. Intl J Hyperthermia 37: 479-485, 2020. PMID: 32396398. DOI: 10.1080/02656736.2020.1763484

27 Robertson S, Hyder O, Dodson R, Nayar SK, Poling J, Beierl K, Eshleman JR, Lin MT, Pawlik TM and Anders RA: The frequency of KRAS and BRAF mutations in intrahepatic cholangiocarcinomas and their correlation with clinical outcome. Hum Pathol 44(12): 2768-2773, 2013. PMID: 24139215. DOI: 10.1016/j.humpath.2013.07.026

28 Voss JS, Holtegaard LM, Kerr SE, Fritcher EG, Roberts LR, Gores GJ, Zhang J, Highsmith WE, Halling KC and Kipp BR: Molecular profiling of cholangiocarcinoma shows potential for targeted therapy treatment decisions. Hum Pathol 44(7): 1216-1222, 2013. PMID: 23391413. DOI: 10.1016/j.humpath.2012.11.006

29 Eckel F and Schmid RM: Chemotherapy in advanced biliary tract carcinoma: a pooled analysis of clinical trials. Br J Cancer 96: 896-902, 2007. PMID: 17325704. DOI: 10.1038/sj.bjc.6603648

30 Rizzo A, Mollica V, Ricci AD, Maggio I, Massucci M, Rojas Limpe FL, Fabio FD and Ardizzoni A: Third- and later-line treatment in advanced or metastatic gastric cancer: a systematic review and meta-analysis. Future Oncol 16(2): 4409-4418, 2020. PMID: 31793342. DOI: 10.2217/fon-2019-0429

31 Mollica V, Di Nunno V, Santoni M, Cimadamore A, Scarpelli M, Lopez-Beltran A, Cheng L, Mariani C, Battelli N, Montironi $\mathrm{R}$ and Massari F: An evaluation of current prostate cancer diagnostic approaches with emphasis on liquid biopsies and prostate cancer. Expert Rev Mol Diagn 20(2): 207-217, 2020. PMID: 31640441. DOI: 10.1080/14737159.2019.1684265

32 Santoni M, Massari F, Del Re M, Ciccarese C, Piva F, Principato G, Montironi R, Santini D, Danesi R, Tortora G and Cascinu S: Investigational therapies targeting signal transducer and activator of transcription 3 for the treatment of cancer. Expert Opin Investig Drugs 24(6): 809-824, 2015. PMID: 25746129. DOI: 10.1517/13543784.2015.1020370

33 Maly V, Maly O, Kolostova K and Bobek V: Circulating tumor cells in diagnosis and treatment of lung cancer. In Vivo 33(4): 1027-1037, 2019. PMID: 31280190. DOI: 10.21873/invivo. 11571

34 Kolostova K, Rzechonek A, Schützner J, Grill R, Lischke R, Hladik P, Simonek J and Bobek V: Circulating tumor cells as an auxiliary diagnostic tool in surgery. In Vivo 31(6): 11971202, 2017. PMID: 29102946. DOI: 10.21873/invivo.11190

35 Ricci AD, Rizzo A, Novelli M, Tavolari S, Palloni A, Tober N, Abbati F, Mollica V, DE Lorenzo S, Turchetti D, DI Marco M and Brandi G: Specific toxicity of maintenance olaparib versus placebo in advanced malignancies: a systematic review and meta-analysis. Anticancer Res 40(2): 597-608, 2020. PMID: 32014900. DOI: 10.21873/anticanres.13989

36 Nygaard AD, Holdgaard PC, Spindler KL, Pallisgaard N and Jakobsen A: The correlation between cell-free DNA and tumour burden was estimated by PET/CT in patients with advanced NSCLC. Br J Cancer 110: 363-368, 2014. PMID: 24231948. DOI: $10.1038 /$ bjc .2013 .705

37 Dawson S-J, Tsui JW, Murtaza M, Biggs H, Rueda OM, Chin SF, Dunning MJ, Gale D, Forshew T, Mahler-Arauho B, Rajan S, Humphray S, Becq J, Halsall D, Wallis M, Bentley D, Caldas $\mathrm{C}$ and Rosenfeld D: Analysis of circulating tumor DNA to monitor metastatic breast cancer. N Engl J Med 368: 11991209, 2013. PMID: 23484797. DOI: 10.1056/NEJMoa1213261
38 Cimadamore A, Massari F, Santoni M, Mollica V, Di Nunno V, Cheng L, Lopez-Beltran A, Scarpelli M, Montironi R and Moch $\mathrm{H}$ : Molecular characterization and diagnostic criteria of renal cell carcinoma with emphasis on liquid biopsies. Expert Rev Mol Diagn 20(2): 141-150, 2020. PMID: 31498685. DOI: 10.1080/14737159.2019.1665510

39 Lee SY, Chae DK, An J, Yoo S, Jung S, Chae CH, Bhak J, Kim $\mathrm{BC}$ and Cho DH: Combinatory analysis of cell-free and circulating tumor cell DNAs provides more variants for cancer treatment. Anticancer Res 39(12): 6595-6602, 2019. PMID: 31810925. DOI: 10.21873/anticanres.13875

40 Buono G, Gerratana L, Bulfoni M, Provinciali N, Basile D, Giuliano M, Corvaja C, Arpino G, Del Mastro L, De Placido S, De Laurentiis M, Cristofanilli M and Puglisi F: Circulating tumor DNA analysis in breast cancer: Is it ready for primetime? Cancer Treat Rev 73: 73-83, 2019. PMID: 30682661 DOI: $10.1016 /$ j.ctrv.2019.01.004

41 Tanaka R, Kimura K, Eguchi S, Tauchi J, Shibutani M, Shinkawa H, Ohira G, Yamazoe S, Tanaka S, Amano R and Tanaka H: Preoperative neutrophil-to-lymphocyte ratio predicts tumor-infiltrating CD8+ $\mathrm{T}$ cells in biliary tract cancer. Anticancer Res 40(5): 2881-2887, 2020. PMID: 32366438. DOI: 10.21873 /anticanres.14264

42 Rizzo A, Pantaleo MA, Saponara S and Nannini M: Current status of the adjuvant therapy in uterine sarcoma: A literature review. World J Clin Cases 7(14): 1753-1763, 2019. PMID: 31417921. DOI: 10.12998/wjcc.v7.i14.1753

43 Modena A, Ciccarese C, Iacovelli R, Brunelli M, Montironi R, Fiorentino M, Tortora G and Massari F: Immune checkpoint inhibitors and prostate cancer: a new frontier? Oncol Rev 10(1): 293, 2016. PMID: 27471580. DOI: 10.4081/oncol.2016.293

44 Komiya K, Nakashima C, Nakamura T, Hirakawa H, Abe T, Ogusu S, Takahashi K, Takeda Y, Egashira Y, Kimura S and Sueoka-Aragane N: Current status and problems of T790M detection, a molecular biomarker of acquired resistance to EGFR tyrosine kinase inhibitors, with liquid biopsy and rebiopsy. Anticancer Res 38(6): 3559-3566, 2018. PMID: 29848710. DOI: 10.21873/anticanres.12628

45 Brandi G, Venturi M, Pantaleo MA, Ercolani G and GICO: Cholangiocarcinoma: Current opinion on clinical practice diagnostic and therapeutic algorithms: A review of the literature and a long-standing experience of a referral center. Dig Liver Dis 48(3): 231-241, 2016. PMID: 26769568. DOI: 10.1016/j.dld.2015.11.017

46 Joo I, Lee JM and Yoon JH: Imaging diagnosis of intrahepatic and perihilar cholangiocarcinoma: recent advances and challenges. Radiology 288(1): 7-13, 2018. PMID: 29869969. DOI: $10.1148 /$ radiol.2018171187

$47 \mathrm{Xu} \mathrm{MM}$ and Sethi A: Diagnosing biliary malignancy. Gastrointest Endosc Clin N Am 25(4): 677-690, 2015. PMID: 26431597. DOI: 10.1016/j.giec.2015.06.011

48 Patel AH, Harnois DM, Klee GG, LaRusso NF and Gores GJ: The utility of CA 19-9 in the diagnoses of cholangiocarcinoma in patients without primary sclerosing cholangitis. Am J Gastroenterol 95(1): 204-207, 2000. PMID: 10638584. DOI: 10.1111/j.1572-0241.2000.01685.x

49 Valle JW, Borbath I, Khan SA, Huguet F, Gruenberger T and Arnold D; ESMO Guidelines Committee: Biliary cancer: ESMO clinical practice guidelines for diagnosis, treatment and follow-up. Ann Oncol 27: v28-v37, 2016. PMID: 27664259. DOI: 10.1093/annonc/mdw324 
50 Rahnemai-Azar AA, Weisbrod A, Dillhoff M, Schmidt C and Pawlik TM: Intrahepatic cholangiocarcinoma: Molecular markers for diagnosis and prognosis. Surg Oncol 26(2): 125-137, 2017. PMID: 28577718. DOI: 10.1016/j.suronc.2016.12.009

51 Levy C, Lymp J, Angulo P, Gores GJ, Larusso N and Lindor KD: The value of serum CA 19-19 in predicting cholangiocarcinomas in patients with primary sclerosing cholangitis. Dig Dis Sci 50: 1734-1740, 2005. PMID: 16133981. DOI: 10.1007/s10620-0052928-8

52 Iavarone M, Piscaglia F, Vavassori S, Galassi M, Sangiovanni A, Venerandi L, Forzenigo LV, Golfieri R, Bolondi L and Colombo M: Contrast enhanced CT-scan to diagnose intrahepatic cholangiocarcinoma in patients with cirrhosis. J Hepatol 58: 1188-1193, 2013. PMID: 23485522. DOI: 10.1016/j.jhep.2013.02.013

53 Nehls O, Gregor M and Klump B: Serum and bile markers for cholangiocarcinoma. Semin Liver Dis 24: 139-154, 2004. PMID: 15192787. DOI: 10.1055/s-2004-828891

54 Oliveira IS, Kilcoyne A, Everett JM, Mino-Kenudson M, Harisinghani MG and Ganesan K: Cholangiocarcinoma: classification, diagnosis, staging, imaging features, and management. Abdom Radiol 42(6): 1637-1649, 2017. PMID: 28271275. DOI: $10.1007 / \mathrm{s} 00261-017-1094-7$

55 Cravo M: Is CA 19-9 of any help in the management of cholangiocarcinoma? GE Port J Gastroenterol 24(3): 108-109, 2017. PMID: 28848793. DOI: 10.1159/000457910

56 Yamashita S, Passot G, Aloia TA, Chun YS, Javle M, Lee JE, Vauthey JN and Conrad C: Prognostic value of carbohydrate antigen 19-9 in patients undergoing resection of biliary tract cancer. Br J Surg 104(3): 267-277, 2017. PMID: 28052308. DOI: $10.1002 / \mathrm{bjs} .10415$

57 Squadroni M, Tondulli L, Gatta G, Mosconi S, Beretta G and Labianca R: Cholangiocarcinoma. Crit Rev Oncol Hematol 116: 11-31, 2017. PMID: 28693792. DOI: 10.1016/j.critrevonc. 2016.11.012

58 Taghavi SA, Eshraghian A, Niknam R, Sivandzadeh GR and Bagheri Lankarani K: Diagnosis of cholangiocarcinoma in primary sclerosing cholangitis. Expert Rev Gastroenterol Hepatol 12(6): 575-584, 2018. PMID: 29781738. DOI: 10.1080/17474124.2018.1473761

59 Baiu I and Visser B: Gallbladder Cancer. JAMA 320(12): 1294, 2018. PMID: 30264121. DOI: 10.1001/jama.2018.11815

60 Massard C, Michiels S, Ferté C, Le Deley MC, Lacroix L, Hollebecque A, Verlingue L, Ileana E, Rosellini S, Ammari S, Ngo-Camus M, Bahleda R, Gazzah A, Varga A, PostelVinay S, Loriot Y, Even C, Breuskin I, Auger N, Job B, De Baere T, Deschamps F, Vielh P, Scoazec JY, Lazar V, Richon C, Ribrag V, Deutsch E, Angevin E, Vassal G, Eggermont A, André $\mathrm{F}$ and Soria JC: High-throughput genomics and clinical outcome in hard-to-treat advanced cancers: results of the MOSCATO 01 trial. Cancer Disco 7(6): 586-595, 2017. PMID: 28365644. DOI: 10.1158/2159-8290.CD-16-1396

61 Valle JW, Lamarca A, Goyal L, Barriuso J and Zhu AX: New horizons for precision medicine in biliary tract cancers. Cancer Disc 7(9): 943-962, 2017. PMID: 28818953. DOI: 10.1158/ 2159-8290.CD-17-0245

62 Lamarca A, Galdy S, Barriuso J, Moghadam S, Beckett E, Rogan J, Backen A, Billington C, McNamara MG, Hubner RA, Cramer A and Valle JW: The HER3 pathway as a potential target for inhibition in patients with biliary tract cancers. PLoS
One 13: e0206007, 2018. PMID: 30335866. DOI: 10.1371/ journal.pone. 0206007

63 Mazzaferro V, el-Rayes BF, Cotsoglou C, Harris WP, Damjanov N, Masi G, Rimassa L, Personeni N, Braiteh FS, Zagonel V, Papadopoulos KP, Hall T, Wang Y, Abbadessa G, Schwartz BE, Kazakin J, Droz Dit Busset M and Shaib WL: ARQ 087, an oral pan-fibroblast growth factor receptor (FGFR) inhibitor, in patients (pts) with advanced intrahepatic cholangiocarcinoma (iCCA) with FGFR2 genetic aberrations. J Clin Oncol 35(15_suppl): 4017, 2017. DOI: 10.1200/JCO.2017.35.15_suppl.4017

64 Javle M, Bekaii-Saab T, Jain A, Wang Y, Kelley RK, Wang K, Kang HC, Catenacci D, Ali S, Krishnan S, Ahn D, Bocobo AG, Zuo M, Kaseb A, Miller V, Stephens PJ, Meric-Bernstam f, Shroff R and Ross J: Biliary cancer: utility of next-generation sequencing for clinical management. Cancer 122(24): 38383847, 2016. PMID: 27622582. DOI: 10.1002/cncr.30254

65 Jusakul A, Cutcutache I, Yong CH, Lim JQ, Huang MN, Padmanabhan N, Nellore V, Kongpetch S, Ng AWT, Ng LM, Choo SP, Myint SS, Thanan R, Nagarajan S, Lim WK, Ng CCY, Boot A, Liu M, Ong CK, Rajasegaran V, Lie S, Lim AST, Lim TH, Tan J, Loh JL, McPherson JR, Khuntikeo N, Bhudhisawasdi V, Yongvanit P, Wongkham S, Totoki Y, Nakamura H, Arai Y, Yamasaki S, Chow PK, Chung AYF, Ooi LLPJ, Lim KH, Dima S, Duda DG, Popescu I, Broet P, Hsieh SY, Yu MC, Scarpa A, Lai J, Luo DX, Carvalho AL, Vettore AL, Rhee H, Park YN, Alexandrov LB, Gordân R, Rozen SG, Shibata T, Pairojkul C, Teh BT and Tan P: Whole-genome and epigenomic landscapes of etiologically distinct subtypes of cholangiocarcinoma. Cancer Disc 7(10): 1116-1135, 2017. PMID: 28667006. DOI: 10.1158/2159-8290.CD-17-0368

66 Verlingue L, Malka D, Allorant A, Massard C, Ferté C, Lacroix L, Rouleau E, Auger N, Ngo M, Nicotra C, De Baere T, Tselikas L, Ba B, Michiels S, Scoazec JY, Boige V, Ducreux M, Soria JC and Hollebecque A: Precision medicine for patients with advanced biliary tract cancers: an effective strategy within the prospective MOSCATO-01 trial. Eur J Cancer 87: 122-130, 2017. PMID: 29145038. DOI: 10.1016/j.ejca.2017.10.013

67 Valle JW, Furuse J, Jitlal M, Baere S, Mizuno N, Wasan H, Bridgewater $\mathrm{J}$ and Okusaka T: Cisplatin and gemcitabine for advanced biliary tract cancer: a meta-analysis of two randomised trials. Ann Oncol 25(2): 391-398, 2014. PMID: 24351397. DOI: $10.1093 /$ annonc/mdt540

68 Vogel A, Kasper S, Bitzer M, Block A, Sinn M, SchulzeBergkamen H, Moehler M, Pfarr N, Endris V, Goeppert B, Merx K, Schnoy E, Siveke JT, Michl P, Waldschmidt D, Kuhlmann J, Geissler M, Kahl C, Evenkamp R, Schmidt T, Kuhlmann A, Weichert W and Kubicka S: PICCA study: panitumumab in combination with cisplatin/gemcitabine chemotherapy in KRAS wild-type patients with biliary cancera randomised biomarker- driven clinical phase II AIO study. Eur J Cancer 92: 11-19, 2018. PMID: 29413685. DOI: 10.1016/j.ejca.2017.12.028

69 Lamarca A, Barriuso J, McNamara MG, Valle JW: Biliary tract Cancer: state of the art and potential role of DNA damage repair. Cancer Treat Rev 70: 168-177, 2018. PMID: 30218788. DOI: $10.1016 /$ j.ctrv.2018.09.002

70 Bogenberger JM, DeLeon TT, Arora M, Ahn DH and Borad MJ: Emerging role of precision medicine in biliary tract cancers. NPJ Precis Oncol 2: 21, 2018. PMID: 30302397. DOI: 10.1038/s41698-018-0064-Z 
71 Lowery MA, Ptashkin R, Jordan E, Berger MF, Zehir A, Capanu M, Kemeny NE, O'Reilly EM, El-Dika I, Jarnaging WR, Harding JJ, D'Angelica MI, Cercek A, Hechtman JF, Solit DB, Schultz N, Hyman DM, Klimstra DS, Saltz LB and AbouAlfa GK: Comprehensive molecular profiling of intrahepatic and extrahepatic cholangiocarcinomas: potential targets for intervention. Clin Cancer Res 24(17): 4154-4161, 2018. PMID: 29848569. DOI: 10.1158/1078-0432.CCR-18-0078

72 Lowery MA, Abou-Alfa GK, Burris HA, Janku F, Shroff RT, Cleary JM, Azad NS, Goyal L, Maher EA, Gore L, Hollebecque A, Beeram M, Trent JC, Jiang L, Ishii Y, Auer J, Gliser C, Agresta SV, Pandya SS and Zhu AW: Phase I study of AG-120, an IDH1 mutant enzyme inhibitor: results from the cholangiocarcinoma dose escalation and expansion cohorts. J Clin Oncol 35(15_suppl): 4015, 2017. DOI: 10.1200/ JCO.2017.35.15_suppl.4015

73 Abou-Alfa GK, Macarulla Mercade T, Javle M, Kelley RK, Lubner S, Adeva J, Cleary JM, Catenacci DV, Borad MJ, Bridgewater JA, Harris WP, Murphy AG, Oh D-Y, Whisenant J, Wu B, Jiang L, Gliser C, Pandya SS, Valle JW and Zhu AW: LBA10_PRClarIDHy: A global, phase III, randomized, doubleblind study of ivosidenib (IVO) vs placebo in patients with advanced cholangiocarcinoma (CC) with an isocitrate dehydrogenase 1 (IDH1) mutation. Ann Oncol 30(Suppl_5), 2019. DOI: $10.1093 /$ annonc/mdz394.027

74 Catarino R, Coelho A, Araújo A, Gomes M, Nogueira A, Lopes C and Medeiros R: Circulating DNA: diagnostic tool and predictive marker for overall survival of NSCLC patients. PLoS One 7: e38559, 2012. PMID: 22701665. DOI: 10.1371/journal.pone. 0038559

75 Pantel K and Alix-Panabières C: Real-time liquid biopsy in cancer patients: fact or fiction? Cancer Res 73(21): 6384-6388, 2013. PMID: 24145355. DOI: 10.1158/0008-5472.CAN-132030

76 Alix-Panabieres C and Pantel K. Circulating tumor cells: liquid biopsy of cancer. Clin Chem 59: 110-118, 2013. PMID: 23014601. DOI: 10.1373/clinchem.2012.194258

77 Schwarzenbach H, Hoon DSB and Pantel K: Cell-free nucleic acids as biomarkers in cancer patients. Nat Rev Cancer 11: 426437, 2011. PMID: 21562580. DOI: $10.1038 /$ nrc3066

78 Bedard PL, Hansen AR, Ratain MJ and Siu LL: Tumour heterogeneity in the clinic. Nature 501: 355-364, 2013. PMID: 24048068. DOI: $10.1038 /$ nature 12627

79 Alix-Panabières $\mathrm{C}$ and Pantel K: Clinical applications of circulating tumor cells and circulating tumor DNA as liquid biopsy. Cancer Discov 6(05): 479-491, 2016. PMID: 26969689. DOI: $10.1158 / 2159-8290 . C D-15-1483$

80 Haber DA and Velculescu VE: Blood-based analyses of cancer: circulating tumor cells and circulating tumor DNA. Cancer Discov 4(06): 650-666, 2014. PMID: 24801577. DOI: 10.1158/2159.8290.CD-13-1014

81 Ciccarese C, Santoni M, Brunelli M, Buti S, Modena A, Nabissi M, Artibani W, Martignoni G, Montironi R, Tortora G and Massari F: AR-V7 and prostate cancer: The watershed for treatment selection? Cancer Treat Rev 43: 27-35, 2016. PMID: 26827690. DOI: 10.1016/j.ctrv.2015.12.003

82 van de Stolpe A, Pantel K, Sleijfer S, Terstappen LW and den Toonder JM: Circulating tumor cell isolation and diagnostics: toward routine clinical use. Cancer Res 71: 5955-5960, 2011. PMID: 21896640. DOI: 10.1158/0008-5472.CAN-11-1254
83 Crowley E, Di Nicolantonio F, Loupakis F and Bardelli A: Liquid biopsy: monitoring cancer-genetics in the blood. Nat Rev Clin Oncol 10: 472-484, 2013. PMID: 23836314. DOI: 10.1038/nrclinonc 2013.110

84 Gold B, Cankovic M, Furtado LV, Meier F and Gocke CD: Do circulating tumor cells, exosomes, and circulating tumor nucleic acids have clinical utility? A report of the Association for Molecular Pathology. J Mol Diagn 17: 209-224, 2015. PMID: 25908243. DOI: 10.1016/j.jmoldx.2015.02.001

85 Nedaeinia R, Manian M, Jazayeri MH, Ranjbar M, Salehi R, Sharifi M, Mohaghegh F, Goli M, Jahednia SH, Avan A and Ghayour-Mobarhan M: Circulating exosomes and exosomal microRNAs as biomarkers in gastrointestinal cancer. Cancer Gene Ther 24: 48-56, 2017. PMID: 27982021. DOI: $10.1038 / \mathrm{cgt}$. 2016.77

86 Mader S and Pantel K: Liquid biopsy: Current status and future perspectives. Oncol Res Treat 40(7-8): 404-408, 2017. PMID: 28693023. DOI: $10.1159 / 000478018$

87 Palmirotta R, Lovero D, Silvestris E, Felici C, Quaresmini D, Cafforio P and Silvestris F: Next-generation sequencing (NGS) analysis on single circulating tumor cells (CTCs) with no need of whole-genome amplification (WGA). Cancer Genomics Proteomics 14(3): 173-179, 2017. PMID: 28446532. DOI: $10.21873 / \operatorname{cgp} .20029$.

88 Mandel $\mathrm{P}$ and Metais P: Les acides nucleiques du plasma sanguin chez l'homme. C R Seances Soc Biol Fil 142: 241-243, 1948. PMID: 18875018

89 Leon SA, Shapiro B, Sklaroff DM and Yaros MJ: Free DNA in the serum of cancer patients and the effect of therapy. Cancer Res 37: 646-650, 1977. PMID: 837366.

90 Normanno N, Cervantes A, Ciardiello F, De Luca A and Pinto C: The liquid biopsy in the management of colorectal cancer patients: Current applications and future scenarios. Cancer Treat Rev 70: 18, 2018. PMID: 30053724. DOI: 10.1016/j.ctrv.2018.07.007

91 Palmirotta R, Lovero D, Cafforio P, Felici C, Mannavola F, Pellè E, Quaresmini D, Tucci M and Silvestris F: Liquid biopsy of cancer: a multimodal diagnostic tool in clinical oncology. Ther Adv Med Oncol 10: 1758835918794630, 2018. PMID: 30181785. DOI: $10.1177 / 1758835918794630$

92 Marusyk A and Polyak K: Tumor heterogeneity: causes and consequences. Biochim Biophys Acta 1805: 105-117, 2010. PMID: 19931353. DOI: 10.1016/j.bbcan.2009.11.002

93 Chang JW, Shih CL, Wang CL, Luo JD, Wang CW, Hsieh JJ, $\mathrm{Yu} \mathrm{CJ}$ and Chiou CC: Transcriptomic analysis in liquid biopsy identifies circulating PCTAIRE-1 mRNA as a biomarker in NSCLC. Cancer Genomics Proteomics 17(1): 91-100, 2020. PMID: 31882554 . DOI: $10.21873 / \operatorname{cgp} .20170$

94 Rossi G, Mu Z, Rademaker AW, Austin LK, Strickland KS, Costa RLB, Nagy RJ, Zagonel V, Taxter TJ, Behdad A, Wehbe FH, Platanias LC, Gradishar WJ and Cristofanilli M: Cell-free DNA and circulating tumor cells: Comprehensive liquid biopsy analysis in advanced breast cancer. Clin Cancer Res 24(3): 560568, 2018. PMID: 29180605. DOI: 10.1158/1078-0432.CCR17-2092

95 Bergerot PG, Hahn AW, Bergerot CD, Jones J and Pal SK: The role of circulating tumor DNA in renal cell carcinoma. Curr Treat Opt Oncol 19: 10, 2018. PMID: 29464405. DOI: 10.1007/s11864-018-0530-4

96 Siravegna G, Marsoni S, Siena S and Bardelli A: Integrating liquid biopsies into the management of cancer. Nat Rev Clin 
Oncol 14: 531-548, 2017. PMID: 28252003. DOI: 10.1038/ nrclinonc.2017.14

97 Cohen JD, Javed AA, Thoburn C, Wong F, Tie J, Gibbs P, Schmidt CM, Yip-Schneider MT, Allen PJ, Schattner M, Brand RE, Singhi AD, Petersen GM, Hong SM, Kim SC, Falconi M, Doglioni C, Weiss MJ, Ahuja N, He J, Makary MA, Maitra A, Hanash SM, Dal Molin M, Wang Y, Li L, Ptak J, Dobbyn L, Schaefer J, Silliman N, Popoli M, Goggins MG, Hruban RH, Wolfgang CL, Klein AP, Tomasetti C, Papadopoulos N, Kinzler $\mathrm{KW}$, Vogelstein B and Lennon AM: Combined circulating tumor DNA and protein biomarker-based liquid biopsy for the earlier detection of pancreatic cancers. Proc Natl Acad Sci USA 114(38): 10202-10207, 2017. PMID: 28874546. DOI: 10.1073/pnas.1704961114

98 Chen K, Zhang H, Zhang L, SQ J, Qi J, Huang DF, Li F, Wei Q and Zhang J: Value of circulating cell-free DNA in diagnosis of hepatocellular carcinoma. World J Gastroenterol 19(20): 31433149, 2013. PMID: 30066898. DOI: 10.3892/mmr.2018.9336.

99 Ellinger J, Wittkamp V, Albers P, Perabo FG, Mueller SC, Von Ruecker A and Bastian PJ: Cell-free circulating DNA: diagnostic value in patients with testicular germ cell cancer. J Urol 181: 363371, 2009. PMID: 19447423. DOI: 10.1016/j.juro.2009.02.106

100 Usiakova Z, Mikulova V, Pinterova D, Brychta M, Valchar J, Kubecova M, Tesarova $\mathrm{P}$, Bobek $\mathrm{V}$ and Kolostova $\mathrm{K}$ : Circulating tumor cells in patients with breast cancer: Monitoring chemotherapy success. In Vivo 28(4): 605-614, 2014. PMID: 24982230.

101 Diehl F, Schmidt K, Choti MA, Romans K, Goodman S, Li M, Thornton K, Agrawal N, Sokoll L, Szabo SA, Kinzler KW, Vogelstein B and Diaz LA Jr.: Circulating mutant DNA to assess tumor dynamics. Nat Med 14: 985-990, 2008. PMID: 18670422. DOI: $10.1038 / \mathrm{nm} .1789$

102 Murtaza M, Dawson SJ, Tsui DW, Gale D, Forshew T, Piskorz AM, Parkinson C, Chin SF, Kingsbury Z, Wong AS, Marass F, Humphray S, Hadfield J, Bentley D, Chin TM, Brenton JD, Caldas $\mathrm{C}$ and Rosenfeld N: Non-invasive analysis of acquired resistance to cancer therapy by sequencing of plasma DNA. Nature 497: 108112, 2013. PMID: 23563269. DOI: 10.1038/nature12065

103 Hao YX, Fu Q, Guo YY, Ye M, Zhao HX, Wang Q, Peng XM, Li QW, Wang RL and Xiao WH: Effectiveness of circulating tumor DNA for detection of KRAS gene mutations in colorectal cancer patients: a meta-analysis. Onco. Targets Ther 10: 945953, 2017. PMID: 28243130. DOI: 10.2147/OTT.S123954

104 Merker JD, Oxnard GR, Compton C, Diehn M, Hurley P, Lazar AJ, Lindeman N, Lockwood CM, Rai AJ, Schilsky RL, Tsimberidou AM, Vasalos P, Billman BL, Oliver TK, Bruinooge SS, Hayes DF and Turner NC: Circulating tumor DNA analysis in patients with cancer: American society of clinical oncology and college of American pathologists joint review. Arch Pathol Lab Med 142: 1242-1253, 2018. PMID: 29504834. DOI: 10.5858/arpa.2018-0901-SA

105 Iijima Y, Hirotsu Y, Amemiya K, Ooka Y, Mochizuki H, Oyama T, Nakagomi T, Uchida Y, Kobayashi Y, Tsutsui T, Kakizaki Y, Goto T, Miyashita Y and Omata M: Very early response of circulating tumour-derived DNA in plasma predicts efficacy of nivolumab treatment in patients with non-small cell lung cancer. Eur J Cancer 86: 349-357, 2017. PMID: 29078173. DOI: 10.1016/j.ejca.2017.09.004

106 Ball MW, Gorin MA, Guner G, Pierorazio PM, Netto G, Paller CJ, Hammers HJ, Diaz LA and Allaf ME: Circulating tumor
DNA as a marker of therapeutic response in patients with renal cell carcinoma: A pilot study. Clin Genitourin Cancer 14: e515e520, 2016. PMID: 27150639. DOI: 10.1016/j.clgc.2016.03.019

107 Pal SK, Sonpavde G, Agarwal N, Vogelzang NJ, Srinivas S, Haas NB, Signoretti S, McGregor BA, Jones J, Lanman RB, Banks KC and Choueiri TK: Evolution of circulating tumor DNA profile from First-line to subsequent therapy in metastatic renal cell carcinoma. Eur Urol 72: 557-564, 2017. PMID: 28413127. DOI: 10.1016/j.eurouro.2017.03.046

108 Li X, Ren R, Ren S, Chen X, Cai W, Zhou F, Zhang Y, Su C, Zhao C, Li J, Cheng N, Zhao M and Zhou C: Peripheral blood for epidermal growth factor receptor mutation detection in nonsmall cell lung cancer patients. Transl Oncol 7: 341-348, 2014. PMID: 25180058. DOI: 10.1016/j.tranon.2014.04.006

109 Mok T, Wu YL, Lee JS, Yu CJ, Sriuranpong V, Sandoval-Tan J, Ladrera G, Thongprasert S, Srimuninnimit V, Liao M, Zhu Y, Zhou C, Fuerte F, Margono B, Wen W, Tsai J, Truman M, Klughammer B, Shames DS and Wu L: Detection and dynamic changes of EGFR mutations from circulating tumor DNA as a predictor of survival outcomes in NSCLC Patients treated with first-line intercalated erlotinib and chemotherapy. Clin Cancer Res 21: 3196-3203, 2015. PMID: 25829397. DOI: 10.1158/ 1078-0432.CCR-14-2594

110 Oxnard GR, Paweletz CP, Kuang Y, Mach SL, O'Connell A, Messineo MM, Luke JJ, Butaney M, Kirschmeier P, Jackman DM and Jänne PA: Noninvasive detection of response and resistance in EGFR-mutant lung cancer using quantitative nextgeneration genotyping of cell-free plasma DNA. Clin Cancer Res 20: 1698-1705, 2014. PMID: 24429876. DOI: 10.1158/ 1078-0432.CCR-13-2482

111 Cimadamore A, Gasparrini S, Santoni M, Cheng L, LopezBeltran A, Battelli N, Massari F, Giunchi, F, Fiorentino M, Scarpelli M and Montironi R: Biomarkers of aggressiveness in genitourinary tumors with emphasis on kidney, bladder, and prostate cancer. Expert Rev Mol Diagn 18: 645-655, 2018. PMID: 29912582. DOI: 10.1080/14737159.2018.1490179

112 Russo M, Siravegna G, Blaszkowsky LS, Corti G, Crisafulli G, Ahronian LG, Mussolin B, Kwak EL, Buscarino M, Lazzari L, Valtorta E, Truini M, Jessop NA, Robinson HE, Hong TS, Mino-Kenudson M, Di Nicolantonio F, Thabet A, SartoreBianchi A, Siena S, Iafrate AJ, Bardelli A and Corcoran RB: Tumor heterogeneity and lesion-specific response to targeted therapy in colorectal cancer. Cancer Discov 6: 147-153, 2016. PMID: 26644315. DOI: 10.1158/2159-8290.CD-15-1283

113 Ghidini M, Pizzo C, Botticelli A, Hahne JC, Passalacqua R, Tomasello $G$ and Petrelli F: Biliary tract cancer: current challenges and future prospects. Cancer Manag Res 11: 379388, 2019. PMID: 30643463. DOI: 10.2147/CMAR.S157156

114 Tamada K, Ushio J and Sugano K: Endoscopic diagnosis of extrahepatic bile duct carcinoma: Advances and current limitations. World J Clin Oncol 2: 203-216, 2011. PMID: 21611097. DOI: 10.5306/wjco.v2.i5.203

115 Zou S, Li J, Zhou H, Frech C, Jiang X, Chu JS, Zhao X, Li Y, Li Q, Wang H, Hu J, Kong G, Wu M, Ding C, Chen N and Hu $\mathrm{H}$ : Mutational landscape of intrahepatic cholangiocarcinoma. Nat Commun 5: 5696, 2014. PMID: 25526346. DOI: 10.1038/ ncomms6696

116 Zill OA, Greene C, Sebisanovic D, Siew LM, Leng J, Vu M, Hendifar AE, Wang Z, Atreya CE, Kelley RK, Van Loon K, Ko AH, Tempero MA, Bivona TG, Munster PN, Talasaz A and 
Collisson EA: Cell-free DNA next-generation sequencing in pancreatobiliary carcinomas. Cancer Discov 5: 1040-1048, 2015. PMID: 26109333. DOI: 10.1158/2159-8290.CD-15-0274

117 Kumari S, Tewari S, Husain N, Agarwal A, Pandey A, Singhal A and Lohani M: Quantification of circulating free DNA as a diagnostic marker in gall bladder cancer. Pathol Oncol Res 23: 9197, 2017. PMID: 27475647. DOI: 10.1007/s12253-016-0087-0

118 Andresen K, Boberg KM, Vedeld HM, Honne H, Jebsen P, Hektoen M, Wadsworth CA, Clausen OP, Lundin KE, Paulsen V, Foss A, Mathisen $\varnothing$, Aabakken L, Schrumpf E, Lothe RA and Lind GE: Four DNA methylation biomarkers in biliary brush samples accurately identify the presence of cholangiocarcinoma. Hepatology 61(05): 1651-1659, 2015. PMID: 25644509. DOI: 10.1002/hep.27707

119 Eaton JE, Gossard AA and Talwalkar JA: Recall processes for biliary cytology in primary sclerosing cholangitis. Curr Opin Gastroenterol 30(03): 287-294, 2014. PMID: 24686433. DOI: 10.1097/MOG.0000000000000055

120 Andersen RF and Jakobsen A: Screening for circulating RAS/RAF mutations by multiplex digital PCR. Clin Chim Acta 458: 138-143, 2016. PMID: 27181912. DOI: 10.1016/j. cca.2016.05.007

121 Mody K, Kasi PM, Yang Y, Surapaneni PK, Bekaii-Saab T, Ahn DH, Mahipal A, Sonbol MB, Starr JS, Roberts A, Nagy R, Lanman R and Borad MJ: Circulating tumor DNA profiling of advanced biliary tract cancers. JCO Precis Oncol 3(3): 1-9, 2019. DOI: $10.1200 / \mathrm{PO} .18 .00324$

122 Lucci A, Hall CS, Lodhi AK, Bhattacharyya A, Anderson AE, Xiao L, Bedrosian I, Kuerer HM and Krishnamurthy S: Circulating tumour cells in non-metastatic breast cancer: a prospective study. Lancet Oncol 13: 688-695, 2012. PMID: 22677156. DOI: 10.1016/S1470-2045(12)70209-7

123 Ansari J, Yun JW, Kompelli AR, Moufarrej YE, Alexander JS, Herrera GA and Shackelford RE: The liquid biopsy in lung cancer. Genes Cancer 7(11-12): 355-367, 2016. PMID: 28191282. DOI: 10.18632/genesandcancer.127

124 Ettrich TJ, Schwerdel D, Dolnik A, Beuter F, Blätte TJ, Schmidt SA, Stanescu-Siegmund N, Steinacker J, Marienfeld R, Kleger A, Bullinger L, Seufferlein T and Berger AW: Genotyping of circulating tumor DNA in cholangiocarcinoma reveals diagnostic and prognostic information. Sci Rep 9(1): 13261, 2019. PMID: 31519967. DOI: 10.1038/s41598-019-49860-0
125 Churi CR, Shroff R, Wang Y, Rashid A, Kang HC, Weatherly J, Zuo M, Zinner R, Hong D, Meric-Bernstam F, Janku F, Crane $\mathrm{CH}$, Mishra L, Vauthey JN, Wolff RA, Mills G and Javle M: Mutation profiling in cholangiocarcinoma: prognostic and therapeutic implications. PLoS One 9(12): e115383, 2014. PMID: 25536104. DOI: 10.1371/journal.pone.0115383

126 Lamarca A, Barriuso J, McNamara MG and Valle JW: Molecular targeted therapies: ready for "prime time" in biliary tract cancer. J Hepatol pii: S0168-8278(20)30165-3, 2020. PMID: 32171892. DOI: 10.1016/j.jhep.2020.03.007

127 Filippi R, Lombardi P, Quarà V, Fenocchio E, Aimar G, Milanesio M, Leone F and Aglietta M: Pharmacotherapeutic options for biliary tract cancer: current standard of care and new perspectives. Expert Opin Pharmacother 20(17): 2121-2137, 2019. PMID: 31550186 . DOI: 10.1080/14656566.2019.1667335

128 Goyal L, Saha SK, Liu LY, Siravegna G, Leshchiner I, Ahronian LG, Lennerz JK, Vu P, Deshpande V, Kambadakone A, Mussolin B, Reyes S, Henderson L, Sun JE, Van Seventer EE, Gurski JM Jr, Baltschukat S, Schacher-Engstler B, Barys L, Stamm C, Furet P, Ryan DP, Stone JR, Iafrate AJ, Getz G, Porta DG, Tiedt R, Bardelli A, Juric D, Corcoran RB, Bardeesy N and Zhu AX: Polyclonal secondary FGFR2 mutations drive acquired resistance to FGFR inhibition in patients with FGFR2 fusion-positive cholangiocarcinoma. Cancer Discov 7(3): 252-263, 2017. PMID: 28034880. DOI: 10.1158/2159-8290.CD-16-1000

129 Shen N, Zhang D, Yin L, Qiu Y, Liu J, Yu W, Fu X, Zhu B, Xu $X$, Duan A, Chen Z, Wang X, Cao X, Zhao T, Zhou Z, Yu L, Qin H, Fang Z, Li JY, Liu Y, Xiong L, Yuan B, Li F and Zhang Y: Bile cell free DNA as a novel and powerful liquid biopsy for detecting somatic variants in biliary tract cancer. Oncol Rep 42(2): 549-560, 2019. PMID: 31173267. DOI: 10.3892/or.2019.7177 